\title{
THE IMPACT OF SYSTEMIC SOLUTIONS IN THE CARE of pregnant women in Poland and England ON THE NUMBER OF VISITS TO A MIDWIFE DURING PREGNANCY AND SUBSEQUENT BREASTFEEDING
}

\author{
Marta Gallas ${ }^{1 \mathrm{~A}, \mathrm{~B}, \mathrm{C}, \mathrm{D}}$, Agnieszka Jankowska ${ }^{2 \mathrm{~B}, \mathrm{C}, \mathrm{E}}$, Aleksandra Gaworska-Krzemińska ${ }^{3,4 \mathrm{E}, \mathrm{F}}$
}

'Division of Nursing Management, Medical University of Gdansk, Poland

${ }^{2}$ Department of Paediatrics, Gastroenterology, Allergology, and Paediatric Nutrition, Medical University of Gdansk, Poland

${ }^{3}$ Department of Nursing and Medical Rescue, Pomeranian University in Slupsk, Poland

${ }^{4}$ Institute of Nursing and Midwifery, Medical University of Gdansk, Poland

Authors' contribution:

A. Study design/planning $\bullet$ B. Data collection/entry $\bullet$ C. Data analysis/statistics $\bullet$ D. Data

interpretation $\bullet$ E. Preparation of manuscript $\bullet$ F. Literature analysis/search $\bullet$ G. Funds collection

\author{
Address for correspondence: \\ Marta Gallas \\ Division of Nursing Management \\ Medical University of Gdansk \\ Gdańsk, Poland \\ e-mail: marta.gallas@gumed.edu.pl \\ SUBMITTED: 21.12 .2021 \\ ACCEPTED: 20.01.2022 \\ DOI: https://doi.org/10.5114/ppiel.2021.113784
}

\begin{abstract}
Aim of the study: To compare the forms of care of pregnant and obstetric women in Poland and Great Britain, as well as to analyse the attitudes and knowledge of Polish and British women about the correct behaviour in this period.

Material and methods: The research was conducted among 111 Polish and 55 British women using the diagnostic survey method with the questionnaire technique, using an anonymous proprietary research tool. The collected material was statistically analysed.

Results: The obtained results showed a statistically significant difference in the number of visits to the midwife and the doctor. Polish women visit a doctor much more often during pregnancy (11 visits) than British women (3 visits), who mostly visit a midwife (7 visits). The conducted study did not show any statistically significant correlation between the number of visits to a midwife or a doctor and the duration of breastfeeding.

Conclusions: The different forms of care (obstetrician-gynaecologist vs. midwife) do not translate into differences in the responding women's level of knowledge and attitudes regarding breastfeeding duration. Considering the different organizational solutions for the care of pregnant women and obstetricians in Poland and Great Britain and the lack of significant differences in the aspects related to breastfeeding in both groups, the awareness of women about the possibility of visiting a midwife during pregnancy should be increased.
\end{abstract}

Key words: knowledge, Poland, pregnancy, midwife, Great Britain.

\section{INTRODUCTION}

According to data from the Central Statistical Office in Poland, in 2018 there were 389,000 live births in Poland [1]. The number of live births in England and Wales in the same year was 657,000 according to the Office for National Statistics in the United Kingdom [2]. The health behaviour of parents towards children, e.g. the way of feeding, consequently influences the subsequent behaviour of adults [3, 4].

Under the Regulation of the Minister of Health of Poland dated 16 August 2018 on the organizational standard of perinatal care, pregnancy care services may be rendered by a physician or a midwife. A pregnant woman is entitled to 8 visits to an obstetrician/ gynaecologist or a midwife. If a pregnant woman decides that a midwife should monitor her pregnancy, an obstetrician/gynaecologist should be consulted 3 times: up to the $10^{\text {th }}$ week of pregnancy, between
24 and 26 weeks of pregnancy, and between 38 and 39 weeks of pregnancy. The remaining 5 appointments are with a midwife [5]. The overseeing obstetrician/gynaecologist should refer a pregnant woman to a midwife within the primary health care system between 21 and 26 weeks of pregnancy. Regardless of who is in charge of pregnancy care, under the Regulation of the President of the Polish National Health Fund dated 27 June 2016 on determining the conditions for the conclusion and implementation of contracts for the provision of healthcare services such as primary health care, a pregnant woman should see a midwife once a week from the $21^{\text {st }}$ to the $31^{\text {st }}$ week of pregnancy, and twice a week from the $32^{\text {nd }}$ week to the end of pregnancy. The aim of those appointments is education, i.e. theoretical and practical preparation for labour, delivery, breastfeeding, and parenthood [5, 6].

Under a regulation of the Polish Minister of Health, the mother and child are entitled to at least 
4 midwife visits at home after discharge. During those visits, the midwife assesses the state of health of the mother and child and the child's physical development, provides parents with guidance on childcare (bathing, changing, etc.), supports the mother in breastfeeding, encourages the mother to engage in physical activity, and informs the partner about where the new mother can receive help in the event of postpartum depression [5, 7].

In the United Kingdom, on the other hand, the first appointment in pregnancy care is with the midwife or with the primary care physician who refers the pregnant woman to a midwife. Quite frequently these midwives work in the nearest hospital, and they are present at delivery. If the pregnancy course does not involve complications, appointments with an obstetrician/gynaecologist are not necessary, and the midwife is the medical professional in charge of overseeing the pregnancy. During the first pregnancy, a woman is entitled to 10 appointments with the midwife, and 7 appointments in subsequent pregnancies. Appointments are held every 3 weeks as of the $25^{\text {th }}$ week of the pregnancy. During an appointment, the midwife educates the patient about the pregnancy stages, delivery, and infant care [8-10]. Around the $10^{\text {th }}$ day after delivery, a health visitor makes an appointment to see the mother and infant. The new mother also receives the contact details of the nearest support group for young parents [8].

\section{MATERIAL AND METHODS}

The study was conducted with the use of a diagnostic survey among 111 Polish women and 55 British women in 2015. A proprietary anonymous survey questionnaire was used. An anonymous online survey tool was posted on Polish and British pregnancy, childbirth, and parenting websites. The collected research material underwent statistical analysis with IBM SPSS 23 Statistics software. Student's $t$-tests were used for independent samples and correlation analysis with Spearman's correlation coefficient. The significance level was $p<0.05$. The $p$ values between 0.05 and 0.10 were considered as indicating a statistical tendency, and we referred to the results assigned to them as marginally significant. In the $t$-test, the reported value for $d$ is Cohen's $d$ statistic.

\section{RESULTS}

Among 166 respondents, the average age of women in the British group was 33 years, and in the group of Polish women it was 30 years. In both countries, about $90 \%$ of respondents declared higher education and living in urban areas. The examined women were in the third trimester of the first pregnancy or less than 3 months after labour and delivery. As shown in
Table 1, British women mainly used public healthcare during pregnancy, while Polish women used private healthcare.

The first item was aimed at obtaining information on whether the use of public or private medical care significantly affected the number of appointments with a midwife.

To assess the responses, Student's $t$-test was conducted for independent samples. The item was analysed separately in the groups of Polish and British women. In the group of Polish women a marginally significant result was obtained showing a statistical tendency $-t(12.84)=-1.985, p=0.069, d=0.894$. Polish women who used medical care as part of the National Health Fund services significantly more often contacted a midwife $(M=7.85, \mathrm{SD}=10.82)$ as compared to Polish women who used private medical care $(M=1.78, S D=2.70)$. Cohen's d value indicates the large effect size. Figure 1 is a graphic representation of the results.

Table 1. Medical care used by women

\begin{tabular}{lcc}
\hline $\begin{array}{l}\text { How was your antenatal care } \\
\text { organized and covered? }\end{array}$ & Poland & $\begin{array}{c}\text { The United } \\
\text { Kingdom }\end{array}$ \\
\hline By Medicare only & $29 \%$ & $77 \%$ \\
\hline Only by private health insurance & $71 \%$ & $14 \%$ \\
\hline Also by private insurance & - & $9 \%$ \\
\hline
\end{tabular}

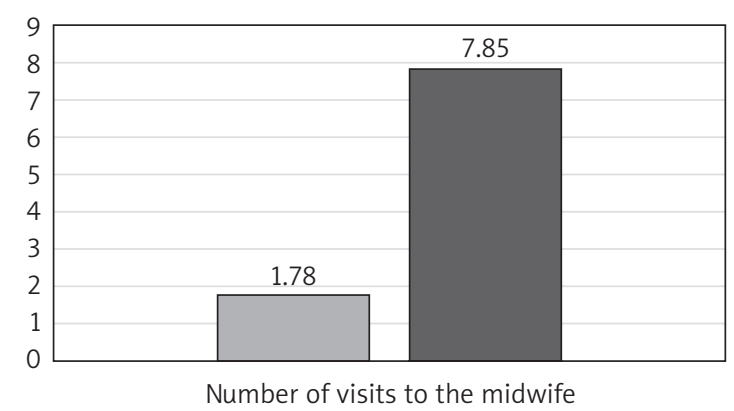

$\square$ Private medical care

Public medical care

Figure 1. Comparison of the number of visits to a midwife among surveyed Polish women who use state and private medical care

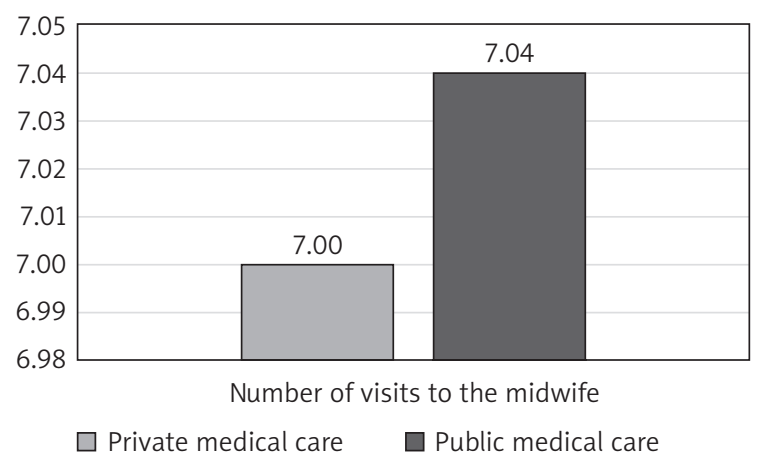

Figure 2. Comparison of the number of visits to a midwife in the group of British women benefiting from public and private medical care 
Table 2. Number of visits to the midwife and doctor in the group of Polish women

\begin{tabular}{lccc}
\hline $\begin{array}{l}\text { Number of visits } \\
\text { to the midwife }\end{array}$ & \multicolumn{2}{l}{ Number of doctor visits } \\
\hline$n$ & $\%$ & $n$ & $\%$ \\
\hline $0-4$ & 86 & $8-10$ & 65 \\
\hline $5-10$ & 8 & $11-14$ & 21 \\
\hline 11 and more & 6 & 15 and more & 14 \\
\hline
\end{tabular}

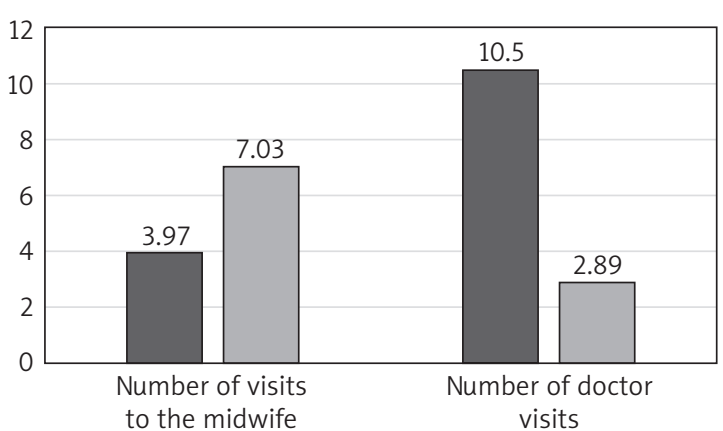

Poland $\square$ The United Kingdom

Figure 3. Comparison of the number of obstetrician and midwife consultations in the Polish and British groups

Subsequently, an analogous analysis was conducted in the group of British women. In this case the result proved to be statistically insignificant $-\mathrm{t}(8.55)=-0.02, p=0.984, d=0.011(\mathrm{M}=7.04$, $S D=2.94$ vs. $M=7.00, S D=4.90)$. Figure 2 is a graphic representation of the results.

Next, we checked whether there was a relationship between the number of appointments with an obstetrician or a midwife in the group of Polish and British women. Most of the Polish women during their pregnancy had 0-4 visits to midwives and 8-10 visits to the doctor. The results are shown in Table 2. The British women had 5-10 visits to the midwife and 0-4 visits to the doctor. The results are presented in Table 3.

The test result was statistically significant. Polish women statistically more often consulted an obstetrician, while the British women more frequently visited a midwife. Cohen's $d$ value indicates that the difference effect is very strong for obstetrician appointments and moderately strong for midwife appointments. Figure 3 is a graphic representation of the results.

The relationship between the number of obstetrician and midwife appointments and breastfeeding was then examined. Polish women plan to breastfeed their baby and give them a bottle if necessary, whereas British women want to breastfeed for as long as possible. The results are presented in Table 4.

Breastfeeding is measured on the ordinal scale, which is why a correlation analysis was performed with the Spearman's correlation coefficient separately for Polish and British women. In both examined
Table 3. Number of visits to the midwife and doctor in the group of British women

\begin{tabular}{lccc}
\hline $\begin{array}{l}\text { Number of visits } \\
\text { to the midwife }\end{array}$ & \multicolumn{2}{l}{ Number of doctor visits } \\
\hline$n$ & $\%$ & $n$ & $\%$ \\
\hline $0-4$ & 17 & $0-4$ & 80 \\
\hline $5-10$ & 74 & $5-10$ & 17 \\
\hline 11 and more & 9 & 11 and more & 3 \\
\hline
\end{tabular}

Table 4. Respondents' answers to the question: Are you going to breastfeed?

\begin{tabular}{lcc}
\hline Are you going to breastfeed? & $\begin{array}{c}\text { Poland } \\
\text { (\%) }\end{array}$ & $\begin{array}{c}\text { United } \\
\text { Kingdom (\%) }\end{array}$ \\
\hline No & 11 & 5 \\
\hline $\begin{array}{l}\text { Yes, and I will feed by bottle if } \\
\text { necessary }\end{array}$ & 51 & 20 \\
\hline $\begin{array}{l}\text { Yes, but only until the } \\
\text { introduction of solid }\end{array}$ & 9 & 17 \\
\hline Yes, as long as possible & 29 & 58 \\
\hline
\end{tabular}

Table 5. Correlation between the number of visits to the midwife and the doctor, and breastfeeding in the group of Polish women

\begin{tabular}{lcc}
\hline & & Breastfeeding \\
\hline Number of visits & rho & 0.148 \\
\cline { 2 - 3 } to the midwife & Statistical significance & 0.390 \\
\hline $\begin{array}{l}\text { Number of doctor } \\
\text { visits }\end{array}$ & rho & -0.082 \\
\cline { 2 - 3 } & Statistical significance & 0.538 \\
\hline
\end{tabular}

rho - Spearman rank correlation coefficient

Table 6. Correlation between the number of visits to the midwife and the doctor, and breastfeeding in the group of British women

\begin{tabular}{lcc}
\hline & & Breastfeeding \\
\hline \multirow{2}{*}{$\begin{array}{l}\text { Number of visits } \\
\text { to the midwife }\end{array}$} & rho & 0.039 \\
\cline { 2 - 3 } & Statistical significance & 0.827 \\
\hline Number of doctor & rho & -0.246 \\
\cline { 2 - 3 } visits & Statistical significance & 0.161 \\
\hline
\end{tabular}

rho-Spearman rank correlation coefficient

groups, the result was not statistically significant, which means that the analysed variables do not correlate in the examined sample (Tables 5 and 6).

\section{DISCUSSION}

Even though both Poland and the United Kingdom base their healthcare systems on their respective national health services, the pregnancy and delivery care is not the same. The basic difference between the discussed systems is the medical professional who offers pregnancy care - usually an obstetrician/ gynaecologist in Poland, and a midwife in the UK. The conducted research indicates that a pregnant Polish patient has an average of 11 obstetrician appoint- 
ments, and a pregnant British patient -3 obstetrician appointments. On average, Polish patients consult midwives 4 times, while British patients have 7 midwife appointments.

In the conducted research, an attempt was made to compare the pregnancy care systems in Poland and the United Kingdom and to assess the relationship between pregnancy care systems and the level of knowledge of new mothers. The obtained results indicate that in Poland, $26 \%$ of respondents benefited from care under the National Health Fund, and on average there were 11 obstetrician appointments and 8 midwife appointments, which is $125 \%$ and $29 \%$ of legally guaranteed appointments, respectively. The respondents who used private healthcare services had an average of 10 obstetrician appointments and 2 private midwife consultations, respectively.

In the United Kingdom, $77 \%$ of respondents used state medical care and on average had 3 obstetrician appointments and 7 midwife appointments. The remaining $33 \%$ of respondents had an average of 4 obstetrician appointments and 7 midwife appointments. The presented results indicate a significant difference between the number of obstetrician-gynaecologist appointments in the groups of Polish and British respondents. Perhaps this is due to the widespread opinion in Poland that obstetrician-gynaecologists are more competent than midwives in pregnancy care and thus enjoy greater trust. Meanwhile, under the regulation of the Minister of Health, a midwife has the necessary knowledge and skills to provide care throughout the entire pregnancy, and there are legal grounds for providing the above-mentioned services [5].

It is also worth noting that Polish health insurance regulations provide for 28 free midwife appointments before delivery. Only $4 \%$ of the surveyed women took advantage of this opportunity, which is probably due to a lack of awareness that they have such a right. A midwife in Poland usually provides care to the new mother and the newborn baby after delivery (minimum 4 additional meetings, apart from the consultations before delivery), while the legally guaranteed 28 meetings before delivery are implemented only to a minor extent $[11,12]$.

In the United Kingdom, according to research conducted by the Care Quality Commission, in 2013 98\% of respondents saw a midwife to confirm pregnancy. Only $22 \%$ needed to consult a general practitioner (GP). When asked if they always received help from a midwife when they needed it, $77 \%$ of women gave an affirmative answer. $97 \%$ of pregnant women had a midwife's phone number and received phone support when necessary [13].

A report from 2015 indicated that $98 \%$ of mothers in Poland started breastfeeding after delivery, in 1997 this was $92 \%$, and a similar result was obtained in this study - 94\% [16]. In the UK, however, in the years
1995-2010, an increase in the percentage of nursing mothers is observed (from $68 \%$ to $83 \%$, respectively), although a slight decrease to $81 \%$ was recorded in 2010-2014 [14]. In this study, a value of $91 \%$ was recorded.

Unfortunately, in the subsequent months of an infant's life, both in Poland and the United Kingdom, a decrease in the number of nursing mothers is observed. In a nationwide report, this ratio was $46 \%$ in the $6^{\text {th }}$ week of the child's life, $42 \%$ in the $2^{\text {nd }}-6^{\text {th }}$ month, and then it reduced to $17 \%$ in the $9^{\text {th }}$ month of the child's life [14].

It is puzzling why the number of nursing mothers so dramatically decreases in the first weeks of a child's life. Perhaps this is due to insufficient awareness of healthcare professionals. According to $25 \%$ of women participating in a nationwide survey, this topic is ignored by healthcare professionals during the hospital stay after delivery [14]. In the UK 57\% of women in a study said they received information from midwives about breastfeeding during pregnancy, and $58 \%$ of women after childbirth breastfed their infants as the only form of feeding [15].

The knowledge of Polish and British respondents regarding pregnancy and breastfeeding is similar but incomplete in some areas. Considering the different pregnancy and maternity care systems in Poland and the United Kingdom, the awareness of women about the possibility of visiting a midwife during pregnancy in Poland should be increased. The expertise of British midwives is no different from that of midwives in Poland. They have the same competence to provide pregnancy care and to educate new mothers about infant care. The question arises: Why are Polish midwives unable to adequately support new mothers through an appropriate number of visits financed by the Polish National Health Fund?

Such a solution could bring measurable benefits to the healthcare system. The waiting time for a specialist appointment would probably be reduced. More frequent use of midwife advice would lead to improving access to their consultations and services. Moreover, it should be expected that the costs would not be higher, because the cost of a midwife appointment is lower than a specialist physician appointment.

\section{CONCLUSIONS}

1. Despite a similar health system, pregnancy medical care is fundamentally different in Poland and the United Kingdom. Polish women prefer obstetriciangynaecologist care, while British patients prefer midwives.

2. The different forms of care (obstetrician-gynaecologist vs. midwife) do not translate into differences in the responding women's level of knowledge and attitudes regarding breastfeeding duration. 
3. In Poland, consideration should be given to promoting pregnancy care provided by midwives, which could reduce the costs of the healthcare system.

\section{Disclosure}

The authors declare no conflict of interest.

\section{References}

1. Podstawowe informacje o rozwoju demograficznym Polski do 2014 roku. Główny Urząd Statystyczny, Warszawa 2015; 1-23.

2. Births by Area of Usual Residence of Mother, UK, 2015.

3. Weber M. Czynniki społeczne i psychologiczne determinujące zachowania żywieniowe dzieci i młodzieży. Zespół Szkół Gastronomicznych, Częstochowa 2015; 133-145.

4. Czerw A. Możliwości kształtowania postaw zdrowotnych dzieci i młodzieży w Polsce. Szkoła Główna Handlowa, Warszawa 2012; 147-157.

5. Rozporządzenie Ministra Zdrowia z dn. 11 września 2018 w sprawie standardów postępowania medycznego przy udzielaniu świadczeń zdrowotnych z zakresu opieki okołoporodowej sprawowanej nad kobietą w okresie fizjologicznej ciąży, fizjologicznego porodu, połogu oraz opieki nad noworodkiem, Warszawa 2018; 1-21.

6. Zarządzenie Narodowego Funduszu Zdrowia z dnia 30 grudnia 2019 r. w sprawie warunków zawarcia i realizacji umów o udzielanie świadczeń opieki zdrowotnej w zakresie podstawowej opieki zdrowotnej, Warszawa 2019; 1-46.

7. www.nhs.uk (dostęp: 6.06.2021)

8. Szajewska H, Socha P, Horvath A, et al. Zasady żywienia zdrowych niemowląt. Stanowisko Polskiego Towarzystwa Gastroenterologii, Hepatologii i Żywienia Dzieci, Standardy Medyczne/Pediatria, Warszawa 2021; 18: 805-822.

9. Mazel S, Murkoff H. Pierwszy rok życia dziecka. Dom Wydawniczy Rebis, Poznań 2017; 27-35.

10. Ćwiek D, Fryc D, Szymoniak K, et al. Poradnik dla kobiet w ciąży i przyszłych rodziców. Zachodniopomorski Oddział Wojewódzki Narodowego Funduszu Zdrowia, Szczecin 2017; 1-48.

11. Najwyższa Izba Kontroli: Informacja o wynikach kontroli realizacji zadań położnych środowiskowych w zakresie podstawowej opieki zdrowotnej. Kraków 2011; 1-60.

12. Najwyższa Izba Kontroli: Wystąpienie pokontrolne P/10/144/ LWR-4101-14-01/2010, Wrocław 2011; 7-36.

13. https://www.gov.uk/government/news/nurse-and-pharmacist-independent-prescribing-changes-announced (dostęp: 6.06.2021)

14. Plotkin L. Support overdue - women's experiences of maternity services. The National Federation of Women's Institutes, London 2017; 1-57.

15. Care Quality Commission: Maternity survey 2019. London 2019; 1-79. 